\title{
Ketoconazole for the Treatment of Docetaxel-Naïve Metastatic Castration-Resistant Prostate Cancer (mCRPC): A Systematic Review
}

\author{
Raden Indra Tresnanda, Sawkar Vijay Pramod*, Ferry Safriadi
}

\begin{abstract}
Objective: This systematic review aimed to determine the efficacy of ketoconazole in the treatment of metastatic castration-resistant prostate cancer (mCRPC). Materials and Methods: A literature search was performed on four databases of PubMed, Google Scholar, Cochrane Database of Systematic Reviews, and Directory of Open Access Journals (DOAJ). The initial search resulted in 602 articles, which were progressively eliminated based on duplication, irrelevancy, and unsuitable methodology. A total of seventeen articles were included in the final analysis, including four randomized controlled trials, nine retrospective cohorts, and four prospective cohorts, with a total population of 1,095 patients. A $200-400 \mathrm{mg}$, tid dose of ketoconazole was used in these studies along with corticoid replacement therapy with hydrocortisone, 20-30 mg in the morning and 10-20 mg in the evening, or prednisone, $5 \mathrm{mg}$, bid. Results: Based on our findings, 8 out of 17 studies reported PSA decrease of $>50 \%$ in approximately half of the population, with a more significant PSA response at $400 \mathrm{mg}$ ketoconazole dosage, and the average progression-free survival (PFS) of 2.6-14.5 months, or time to progression of 3.2-6.7 months. Conclusion: Ketoconazole with corticosteroid could be an effective alternative for the treatment of $\mathrm{mCRPC}$ with a satisfactory PSA response and disease progression.
\end{abstract}

Keywords: Ketoconazole- Corticosteroid- mCRPC- PSA- PFS- Response

Asian Pac J Cancer Prev, 22 (10), 3101-3107

\section{Introduction}

Prostate cancer is the most common malignancy in men. Worldwide, prostate cancer is the third most common cancer after lung and breast cancers, and the second most common cancer in men after lung cancer (Bray et al., 2018; Rawla et al., 2019). This cancer has a significant morbidity and mortality burden, with annual losses of 7.1 million disability-adjusted life-years (DALYs) and more than 358.000 deaths in 2018 (Rawla et al., 2019; Global Burden of Disease Cancer Collaboration; 2019). Metastatic castration-resistant prostate cancer (mCRPC) is a subtype of prostate cancer having a poor prognosis. The average survival rate of this subtype is less than two years after diagnosis contributing to a large number of deaths from prostate cancer (Frieling et al., 2015). CRPC is defined by prostate cancer progression and signified by an increase of tumor volume during radiographic evaluation and continuous increase in prostate-specific antigen (PSA) levels on three different occasions, despite a castrate level of testosterone (less than $50 \mathrm{ng} / \mathrm{dL}$ ) (Fong et al., 2012).

The standard treatment for CRPC is androgen deprivation therapy with the addition of secondary hormonal manipulation, chemotherapy, and radiotherapy. Androgen deprivation is usually achieved through the use of anti-androgenic agents, including abiraterone or enzalutamide, in addition to androgen synthesis inhibitors, such as ketoconazole and corticosteroid replacement therapy. The standard chemotherapeutic agents for CRPC include alkaloids, such as docetaxel, or anthracenediones, such as mitoxantrone (Teo et al., 2019). However, chemotherapy is well known for the side effects, such as diarrhea, nausea and vomiting, risk of infection, and bleeding (American Cancer Society medical and editorial content team, 2019).

In Indonesia, malignancies are one of the costliest diseases in the health care system. A study by Budiarto and Sugiharto (2013) stated that cancer took the second-highest cost in the Indonesian Case-Based Groups (INA-CBGs) after cardiovascular diseases with a total cost per patient of 4,805 USD (American Cancer Society medical and editorial content team, 2019; Budiarto et al., 2012). Moreover, not all prostate cancer chemotherapy agents are covered by national health insurance or private insurance, limiting therapeutic options for these patients. Although there are no available official epidemiologic data of prostate cancer in Indonesia currently, Hasan 
Sadikin Academic Medical Center reported that 39.3\% of patients with prostate cancer treated in the hospital experienced metastatic progression. A report by the Indonesian Ministry of Health showed that approximately $10 \%$ of prostate cancer cases in Indonesia progressed to CRPC. Several new therapeutic agents for CRPC, such as sipuleucel-T, enzalutamide, radium-233, abiraterone, estramustine, and cabazitaxel, are currently not approved for use in Indonesia, thus they are not covered by the Indonesian national health insurance system. Therefore, a safe, efficient, and economical alternative is needed for mCRPC patients in Indonesia (Komite Penanggulangan Kanker Nasional., 2016).

Ketoconazole is a synthetic imidazole antifungal agent commonly used in the treatment of dermatophytosis or systemic fungal infections, including blastomycosis, histoplasmosis, paracoccydiomycosis, coccydiomycosis, and chromomycosis. Ketoconazole is a nonspecific cytochrome P450 inhibitor, which may inhibit gonadal and adrenal steroid synthesis (Sinawe et al., 2020). Furthermore, ketoconazole inhibits CYP17A1, a catalyst for two key reactions in the production of gonadal and extragonadal steroid hormones (androgen and testosterone), as shown in Figure 1 (Sinawe et al., 2020). Considering the limitations of chemotherapy in Indonesia, including the availability of drugs and facilities, the lack of oncological expertise, the high cost of chemotherapy, and the higher toxicity, our study was performed to determine the effectiveness of ketoconazole for the treatment of mCRPC.

\section{Materials and Methods}

This systematic review was done through searching PubMed, Cochrane Database of Systematic Reviews, Google Scholar, and Directory of Open Access Journals (DOAJ). The literature search was carried out with no time limitations using the keywords of ketoconazole, metastatic castrate-resistant prostate cancer, and mCRPC. A literature search was also performed on synonyms of mCRPC, including advanced prostate cancer, androgen-independent prostate cancer, hormone refractory prostate cancer, and rogressive androgen-independent prostate cancer. Studies that used ketoconazole after docetaxel chemotherapy were excluded from the analysis. This systematic review was performed according to the PRISMA guidelines (Moher et al., 2010).

All articles obtained from the initial search were analyzed in four steps. The first step was filtering the articles based on the searched keywords. The second step was analyzing the title and abstract based on the inclusion and exclusion criteria. In the third step, the generalized text was analysed based on the inclusion and exclusion criteria. In the fourth step, cross-referenced articles in other systematic reviews or studies. The number of eliminated articles is described in Figure 2.

\section{Results}

Out of seventeen included studies, four studies were randomized controlled trials (RCT), nine studies were retrospective cohorts, and four studies were prospective cohorts. All studies were done on a population of patients with prostate cancer resistant to metastatic castration and naïve to docetaxel. All of the studies used ketoconazole, 200 to $400 \mathrm{mg}$, tid as the primary intervention. Fifteen of the seventeen studies used hydrocortisone, prednisone, or prednisolone as an alternative therapy to prevent corticosteroid deficiency due to long-term use of ketoconazole.

\section{PSA response and disease progression}

All of the analyzed studies reported a significant decrease in serum PSA $(>50 \%)$ in $\mathrm{mCRPC}$ patients
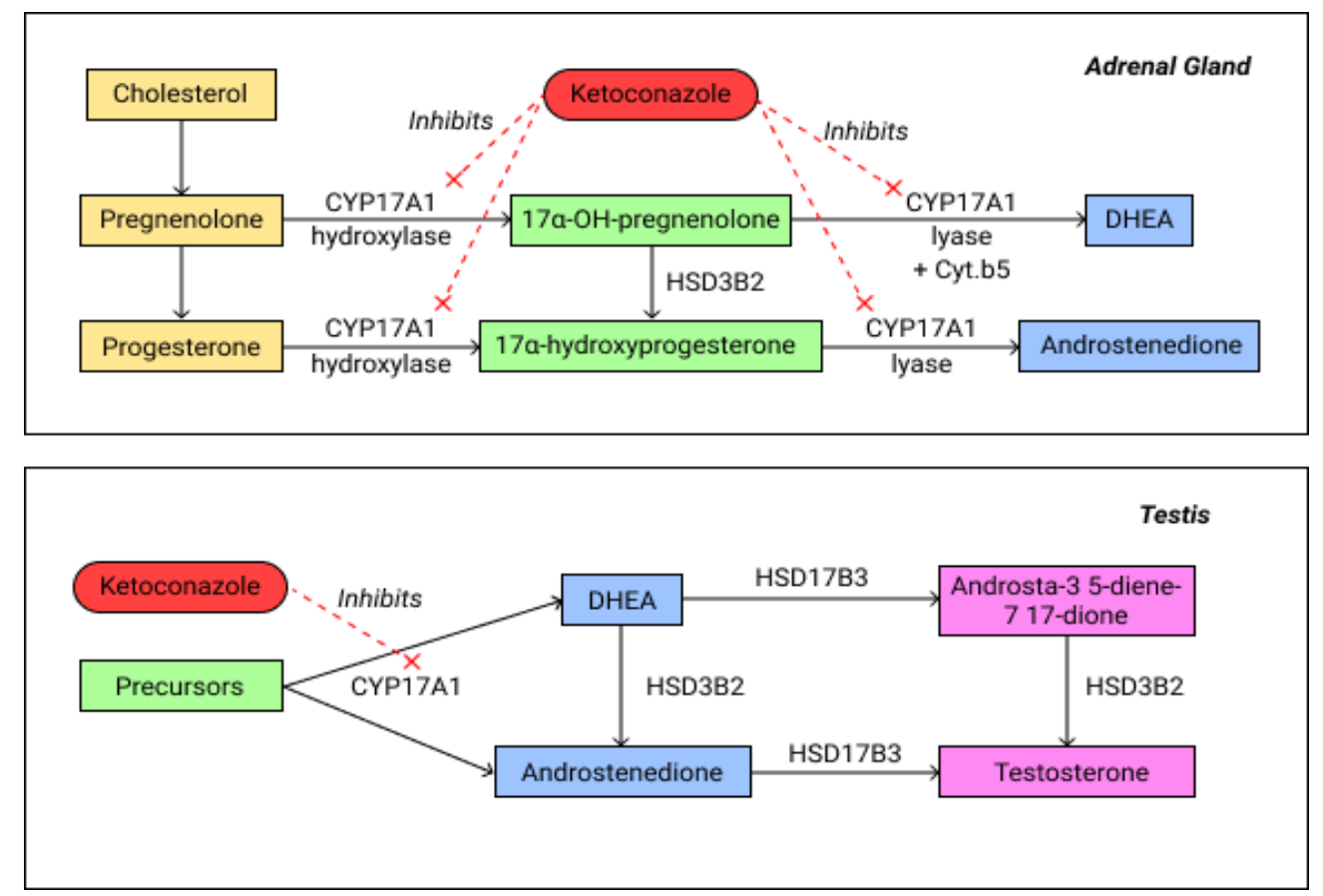

Figure 1. The Role of Ketoconazole in Inhibiting Gonadal Steroid Hormone Synthesis (Patel., 2018) 
DOI:10.31557/APJCP.2021.22.10.3101

A Systematic Review on the Efficacy of Ketoconazole

Table 1. Summary of Analyzed Studies

\begin{tabular}{|c|c|c|c|c|c|}
\hline $\begin{array}{l}\text { Investigators, } \\
\text { Year }\end{array}$ & Design & Subjects & Intervention & $\begin{array}{l}\text { PSA Response and Disease } \\
\text { Progression }\end{array}$ & Ketoconazole Toxicity \\
\hline $\begin{array}{l}\text { Small, et al. } \\
\text { 1997, USA }\end{array}$ & Prospective cohort & 48 & $\begin{array}{l}\text { Ketoconazole } \\
3 \times 400 \mathrm{mg}+ \\
\text { hydrocortisone } \\
20 \mathrm{mg}-0-10 \mathrm{mg}\end{array}$ & $\begin{array}{c}\cdot>50 \% \text { PSA response in } 62.5 \% \\
\text { patients } \\
\cdot \text { Median progression-free } \\
\text { survival of } 4 \text { months } \\
\cdot \text { Median duration of response was } \\
3.5 \text { months (range } 2-12 \text { months) } \\
\cdot \text { Range time to reach PSA } \\
\text { decrease was 3-10 months }\end{array}$ & $\begin{array}{l}\text { Hepatotoxicity in } 2 \text { patients } \\
\text {. Nausea and anorexia in } 3 \\
\text { patients } \\
\text { Congestive heart failure in } \\
1 \text { patient }\end{array}$ \\
\hline $\begin{array}{l}\text { Millikan, } \\
\text { et al. 2001, USA }\end{array}$ & Randomized controlled trial & 45 & $\begin{array}{l}\text { Ketoconazole } \\
3 \times 400 \mathrm{mg}\end{array}$ & $\begin{array}{l}\cdot \text { PSA response in } 31 \% \text { patients } \\
\text { - Median time to progression was } \\
3.3 \text { months }\end{array}$ & $\begin{array}{c}\cdot \text { Dominated by } \\
\text { gastrointestinal complaints } \\
\cdot 1 \text { patient had grade } 4 \\
\text { hepatotoxicity }\end{array}$ \\
\hline $\begin{array}{l}\text { Harris, } \\
\text { et al. 2002, USA }\end{array}$ & Prospective cohort & 28 & $\begin{array}{l}\text { Ketoconazole } \\
3 \times 200 \mathrm{mg}+ \\
\text { hydrocortisone } \\
20 \mathrm{mg}-0-10 \mathrm{mg}\end{array}$ & $\begin{array}{l}46 \% \text { had a PSA decrease }>50 \% \\
\cdot \text { Median duration of PSA } \\
\text { response was } 7.5 \text { months }\end{array}$ & $\begin{array}{l}\cdot \text { Nausea in } 29 \% \text { patients } \\
\cdot \text { Dry skin in } 18 \% \text { patients } \\
\text { - Liver effects in } 8 \% \text { patients }\end{array}$ \\
\hline $\begin{array}{l}\text { Wilkinson \& } \\
\text { Chodak 2004, } \\
\text { USA }\end{array}$ & Retrospective cohort & 38 & $\begin{array}{l}\text { Ketoconazole } \\
3 \times 300 \mathrm{mg}+ \\
\text { hydrocortisone } \\
20 \mathrm{mg}-0-10 \mathrm{mg}\end{array}$ & $\begin{array}{c}\cdot>50 \% \text { PSA response in } 55.3 \% \\
\text { patients } \\
\cdot \text { Median time to progression of } 5 \\
\text { months (range } 0-27 \text { months) } \\
\cdot \text { Median duration of response was } \\
6 \text { months (range } 3-48 \text { months) } \\
\text { - PSA response to ketoconazole } \\
\text { can be identified within the first } \\
6-8 \text { weeks of therapy }\end{array}$ & $\begin{array}{l}31.6 \% \text { patients reported } \\
\text { toxicity symptoms }\end{array}$ \\
\hline $\begin{array}{l}\text { Argirovic 2005, } \\
\text { Serbia }\end{array}$ & Retrospective cohort & 35 & $\begin{array}{l}\text { Ketoconazole } \\
3 \times 400 \mathrm{mg}+ \\
\text { hydrocortisone } \\
20 \mathrm{mg}-0-10 \mathrm{mg}\end{array}$ & $\begin{array}{c}\text { PSA response to ketoconazole } \\
\text { can be identified within the first } \\
6-8 \text { weeks of therapy } \\
\cdot>50 \% \text { PSA response in } 51.4 \% \\
\text { patients } \\
\text { - Median time to progression of } \\
6.3 \text { months (range } 0-27 \text { months) } \\
\cdot \text { Mean duration of response was } 6 \\
\text { months (range } 3-48 \text { months) }\end{array}$ & $\begin{array}{l}34.3 \% \text { patients reported } \\
\text { grade } 1-2 \text { toxicity symptoms }\end{array}$ \\
\hline $\begin{array}{l}\text { Figg, et al. } 2005 \text {, } \\
\text { USA }\end{array}$ & Randomized controlled trial & 36 & $\begin{array}{l}\text { Ketoconazole } \\
3 \times 400 \mathrm{mg}+ \\
\text { hydrocortisone } \\
30 \mathrm{mg}-0-10 \mathrm{mg}\end{array}$ & $\begin{array}{c}\cdot \text { PSA response in } 47 \% \text { patients } \\
\cdot \text { Median progression free } \\
\text { survival was } 3.8 \text { months } \\
\cdot \text { Median duration of response was } \\
6.3 \text { months }\end{array}$ & $\begin{array}{l}58 \% \text { patients had grades } 1 \\
\text { and } 2 \text { toxicity } \\
3 \% \text { patients had grade } 3 \\
\text { toxicity }\end{array}$ \\
\hline $\begin{array}{l}\text { Scholz, et al. } \\
2005 \text {, USA }\end{array}$ & Retrospective cohort & 78 & $\begin{array}{l}\text { Ketoconazole } \\
3 \times 200-400 \mathrm{mg}+ \\
\text { hydrocortisone } \\
2 \times 20 \mathrm{mg}\end{array}$ & $\begin{array}{c}\cdot>75 \% \text { PSA response in } 44 \% \\
\text { patients } \\
\text { - Median time to progression was } \\
6.7 \text { months } \\
\text { - Mean time to progression was } \\
14.5 \text { months }\end{array}$ & No severe toxicity reported \\
\hline $\begin{array}{l}\text { Nakabayashi, et } \\
\text { al., 2006, USA }\end{array}$ & Prospective cohort & 138 & $\begin{array}{l}\text { Ketoconazole } \\
3 \times 200-400 \mathrm{mg}+ \\
\text { hydrocortisone } \\
40 \mathrm{mg} / \text { day OR } \\
\text { prednisone } \\
10 \mathrm{mg} / \text { day }\end{array}$ & $\begin{array}{l}50 \% \text { PSA response in } 28.3 \% \\
\text { patients } \\
\text { Median time to progression of } \\
3.2 \text { months (range } 0.1-61 \text { months) } \\
\text { - Median duration of response in } \\
\text { high dose ketoconazole was } 3.6 \\
\text { months (range } 0.5-32.2 \text { months) } \\
\text { Median duration of response } \\
\text { in low dose ketoconazole was } 3 \\
\text { months (range } 0.1-62.4 \text { months) }\end{array}$ & $\begin{array}{c}\text { 10.9\% patients experienced } \\
\text { grade } 3 \text { toxicity } \\
\text { - Fatigue in } 13.5 \% \text { patients } \\
\text { - Anorexia in } 6.0 \% \text { patients } \\
\text { - Nausea in } 5.3 \% \text { patients } \\
\text { - Diarrhea in } 4.5 \% \text { patients }\end{array}$ \\
\hline $\begin{array}{l}\text { Ngo, et al., } \\
\text { 2007, Singapore }\end{array}$ & Retrospective cohort & 32 & $\begin{array}{c}\text { Ketoconazole } \\
3 \times 200 \mathrm{mg}+ \\
\text { hydrocortisone OR } \\
\text { prednisolone } \\
\text { (no reported dosage) }\end{array}$ & $\begin{array}{c}\cdot 50 \% \text { PSA response in } 38 \% \\
\text { patients } \\
\cdot \text { Median duration of response was } \\
6.75 \text { months (range } 2-14 \text { months, } \\
\text { mean } 7.75 \text { months) } \\
\cdot \text { Median time to reach PSA } \\
\text { nadir was } 3.5 \text { months (range } \\
1.5-11 \text { months, mean } 4.7 \text { months) }\end{array}$ & $\begin{array}{c}56 \% \text { reported toxicity } \\
\text { symptoms } \\
\cdot \text { Abnormal liver function } \\
\text { test in } 41 \% \text { patients }\end{array}$ \\
\hline $\begin{array}{l}\text { Akhtar 2009, } \\
\text { Bangladesh }\end{array}$ & Retrospective cohort & 10 & $\begin{array}{l}\text { Ketoconazole } \\
3 \times 200 \mathrm{mg}\end{array}$ & $\begin{array}{c}\cdot>50 \% \text { PSA response in } 40 \% \\
\text { patients } \\
\cdot \text { Median duration of response of } \\
6.75 \text { months (range } 2-14 \text { months) } \\
\cdot \text { Median time to reach PSA nadir } \\
\text { was } 5.06 \text { months }(1.5-11 \text { months) }\end{array}$ & $\begin{array}{c}50 \% \text { patients reported grades } \\
1 \text { and } 2 \text { toxicity symptoms }\end{array}$ \\
\hline
\end{tabular}


Table 1. Continued

\begin{tabular}{|c|c|c|c|c|c|}
\hline $\begin{array}{l}\text { Investigators, } \\
\text { Year }\end{array}$ & Design & Subjects & Intervention & $\begin{array}{l}\text { PSA Response and Disease } \\
\text { Progression }\end{array}$ & Ketoconazole Toxicity \\
\hline $\begin{array}{l}\text { Yun, et al. 2011, } \\
\text { South Korea }\end{array}$ & Retrospective cohort & 39 & $\begin{array}{c}\text { Ketoconazole } \\
3 \times 200 \mathrm{mg}+ \\
\text { Prednisolone } 2 \times 5 \mathrm{mg}\end{array}$ & $\begin{array}{c}\cdot \text { PSA response in } 33.3 \% \text { patients } \\
\cdot \text { Median progression-free } \\
\text { survival was } 5 \text { months } \\
\text { - Early time to reach PSA decrease } \\
\text { was within the } 1 \text { st } 4 \text { weeks }\end{array}$ & $\begin{array}{c}\text { - Nausea/vomitting in } \\
20(51.3 \%) \text { patients } \\
\cdot \text { Anorexia in } 15(38.5 \%) \\
\text { patients } \\
\text { - Facial edema in } 11(28.2 \%) \\
\text { patients } \\
\text { - Gynecomastia in } 3(7.7 \%) \\
\text { patients } \\
\text { - Liver toxicity in } 9(23.1 \%) \\
\text { patients }\end{array}$ \\
\hline $\begin{array}{l}\text { Chiang, et al., } \\
\text { 2012, Taiwan }\end{array}$ & Retrospective cohort & 44 & $\begin{array}{c}\text { Ketoconazole } \\
3 \times 200 \mathrm{mg}+ \\
\text { prednisolone }(37) \mathrm{vs} \\
\text { ketoconazole } \\
3 \times 400 \mathrm{mg}+ \\
\text { prednisolone }(7)\end{array}$ & $\begin{array}{l}\text { - PSA response was } 37.8 \% \text { in } 200 \\
\text { mg group and } 57.1 \% \text { in } 400 \mathrm{mg} \\
\text { group } \\
\text { - Median time to progression was } \\
7.5 \text { months (range } 1-87 \text { months) } \\
\text { in } 200 \mathrm{mg} \text { group and } 11.5 \text { months } \\
\text { (range } 4-16.5 \text { months) in } 400 \mathrm{mg} \\
\text { group } \\
\text { - Median duration of response was } \\
5.5 \text { months (range } 0.5-86 \text { months) } \\
\text { in } 200 \mathrm{mg} \text { group and } 9 \text { months } \\
\text { (range } 2-13 \text { months) in } 400 \mathrm{mg} \\
\text { group }\end{array}$ & $\begin{array}{c}9.1 \% \text { patients had grade } 1 \\
\text { or } 2 \text { toxicity } \\
\cdot 2,3 \% \text { patients had grade } 3 \\
\text { elevated liver function }\end{array}$ \\
\hline $\begin{array}{l}\text { Keizman, et al. } \\
\text { 2012, USA }\end{array}$ & Prospective cohort & 114 & $\begin{array}{l}\text { Ketoconazole } \\
3 \times 200-400 \mathrm{mg}+ \\
\text { hydrocortisone } \\
30 \mathrm{mg}-0-10 \mathrm{mg}\end{array}$ & $\begin{array}{c}\cdot 50 \% \text { PSA response in } 54 \% \\
\text { patients } \\
\cdot 16 \text { patients remained progression } \\
\text { free with a median treatment time } \\
\text { of } 12 \text { months } \\
\cdot \text { Median time to progression was } \\
8 \text { months (range } 1-129 \text { months, } \\
\text { mean } 12.8 \text { months) } \\
\cdot \text { Median duration of response was } \\
12 \text { months (range } 6-122 \text { months, } \\
\text { mean } 29.9 \text { months) }\end{array}$ & $\begin{array}{l}22 \% \text { patients had grade } 3 \text { or } \\
4 \text { toxicity }\end{array}$ \\
\hline $\begin{array}{l}\text { Keizman, et al. } \\
\text { (2) 2012, USA }\end{array}$ & Retrospective cohort & 156 & $\begin{array}{l}\text { Ketoconazole } \\
3 \times 200-400 \mathrm{mg}+ \\
\text { hydrocortisone } \\
30 \mathrm{mg}-0-10 \mathrm{mg}\end{array}$ & $\begin{array}{l}\cdot 50 \% \text { PSA response in } 50 \% \\
\text { patients } \\
\cdot \text { Median duration of response } \\
\text { was } 4 \text { months (range } 1-55 \text { months, } \\
\text { mean } 6.8 \text { months) }\end{array}$ & $\begin{array}{c}17 \% \text { patients had grade } 3 \text { or } \\
4 \text { toxicity }\end{array}$ \\
\hline $\begin{array}{l}\text { Lin, et al. } 2012 \text {, } \\
\text { China }\end{array}$ & Retrospective cohort & 163 & $\begin{array}{c}\text { Ketoconazole } \\
3 \times 200-400 \mathrm{mg} \\
+ \text { Prednisone } 2 \times 5 \mathrm{mg}\end{array}$ & $\begin{array}{c}\cdot \geq 50 \% \text { PSA response in } 31.9 \% \\
\text { patients } \\
\cdot \text { Median progression-free } \\
\text { survival was } 2.6 \text { months } \\
(0.5-8.6 \text { months }) \\
\text { Median time to reach PSA nadir } \\
\text { was } 1.4 \text { months }\end{array}$ & $\begin{array}{c}\cdot \text { Abnormal liver function } \\
(9.2 \%) \\
\cdot \text { Abnormal renal function } \\
(8.6 \%) \\
\cdot 1.8 \% \text { had grade } 3 \text { toxicity }\end{array}$ \\
\hline $\begin{array}{l}\text { Taplin, et al., } \\
\text { 2013, USA }\end{array}$ & Randomized controlled trial & 57 & $\begin{array}{l}\text { Ketoconazole } \\
3 \times 400 \mathrm{mg}+ \\
\text { hydrocortisone } \\
30 \mathrm{mg}-0-10 \mathrm{mg}\end{array}$ & $\begin{array}{c}\text { - Decrease in PSA in } 56 \% \text { patients } \\
\cdot \text { RECIST (response evaluation } \\
\text { criteria in solid tumors) response } \\
\text { in } 30 \% \text { patients } \\
\text { - Median duration of response was } \\
20 \text { months } \\
\text { - Median time to progression was } \\
14.5 \text { months }\end{array}$ & $\begin{array}{l}32 \% \text { patients had grade } \\
3 \text { toxicity }\end{array}$ \\
\hline $\begin{array}{l}\text { Barata, et al. } \\
2018\end{array}$ & Randomized controlled trial & 34 & $\begin{array}{l}\text { Ketoconazole } \\
3 \times 400 \mathrm{mg}+ \\
\text { hydrocortisone } \\
30 \mathrm{mg}-0-10 \mathrm{mg}\end{array}$ & $\begin{array}{c}\text { PSA response in } 50 \% \text { patients } \\
\text { Median time to failure was } 2.7 \\
\text { months }(0.2-32.8 \text { months })\end{array}$ & $\begin{array}{l}\text { Most common adverse } \\
\text { events: fatigue }(76 \%) \text {, skin } \\
\text { reactions }(62 \%), \\
\text { lymphopenia }(44 \%) \text { and } \\
\text { anemia }(44 \%)\end{array}$ \\
\hline
\end{tabular}

receiving ketoconazole. Eight studies reported PSA response in $>50 \%$ of patients. Scholz et al., (2005) reported a PSA response $>75 \%$ in $44 \%$ of patients. While Chiang et al., (2012) reported a greater decrease in PSA in the group receiving $400 \mathrm{mg}$ ketoconazole, compared to the group receiving $200 \mathrm{mg}$ ketoconazole. Based on disease progression, which was assessed by the duration of progression-free survival (PFS), Small et al., (1997) reported a median PFS of 4 months, Chiang et al., (2012) reported a PFS of 7.5-11.5 months, Keizman et al., (2012) a PFS of 8 months, Keizman et al., (2012) a PFS of 8 months, Lin (2012) a PFS of 2.6 months (0.5 to 8.6 months), Millikan et al., (2001) a PFS of 3,3 months, Taplin et al., (2009) a PFS of 14.5 months, and Yun et al., (2011) a PFS of 8 months (Barata et al., 2018; Chiang et al., 2012; Keizman et al., 2012; Lin et al., 2012; Millikan et al., 2001; Taplik et al., 2009; Yun et al., 2011; Scholz et al., 2005).

Several other studies reported various time to progression. For instance, Harris et al., (2002) reported 


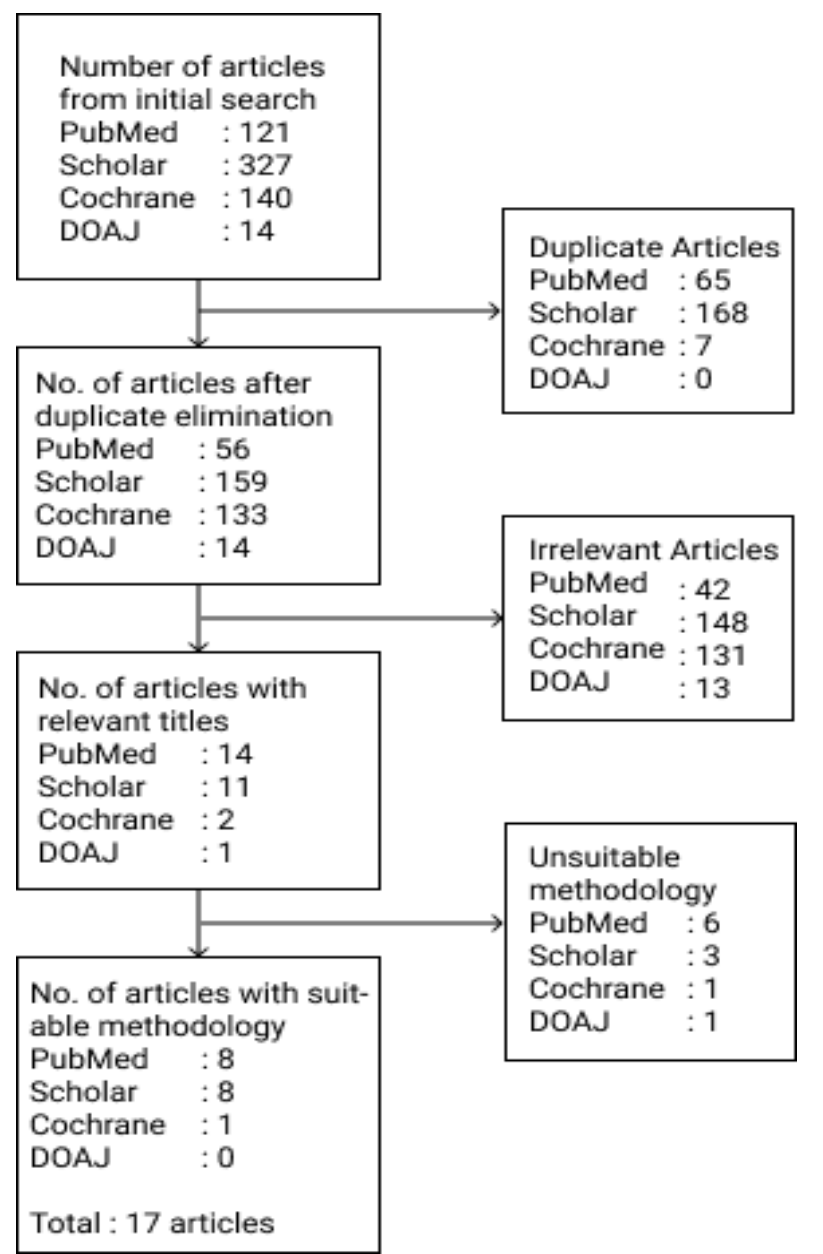

Figure 2. Article Elimination Flowchart

time to progression of 30 weeks, Wilkinson and Chodak (2004) of 5 months, Argirovic et al., (2005) of 6.3 months, Nakabayashi et al., (2006) of 3.2 months, Akhtar et al., (2009) of 6.75 months, and Ngo et al., (2007) of 6.75 months. Figure 3 illustrates the results of these studies in detailes (Harris et al., 2002; Wilkinson et al., 2004; Argirović et al., 2005; Akhtar et al., 2009; Ngo et al., 2007; Nakabayashi et al., 2006).

\section{Ketoconazole Toxicity}

Ketoconazole generally shows a good safety profile, although its toxicity should be considered in managing mCRPC patients. Administration of systemic ketoconazole most commonly causes gastrointestinal side effects, including nausea, vomiting, constipation, abdominal pain, dry mouth, and discoloration of the tongue. Inhibition of steroid synthesis may result in adrenal insufficiency, which may consequently lead to orthostatic hypotension and side effects associated with sex hormones, including gynecomastia (Sinawe et al., 2020). Therefore, long-term administration of ketoconazole must be accompanied by replacement therapy using corticosteroids. The most severe symptoms of toxicity are generally associated with hepatotoxicity, which can cause jaundice, severe hepatitis, and liver failure (National Institute of Health, 2017).

Almost all studies used the National Cancer Institute Common Toxicity Criteria monitoring system to evaluate and analyze ketoconazole toxicity. The symptoms of grade 3-4 toxicity indicate poor tolerance by the patient and require cessation of the regimen as soon as possible. If the symptoms of toxicity have improved to degrees 1 or 2 , the regimen can be restarted with a reduced dose. The summary of the analyzed studies is described in Table 1.

\section{Discussion}

Secondary hormonal manipulation is a suitable therapeutic option to reduce the burden of disease and improve patients' quality of life with CRPC. Ketoconazole is a nonspecific cytochrome P450
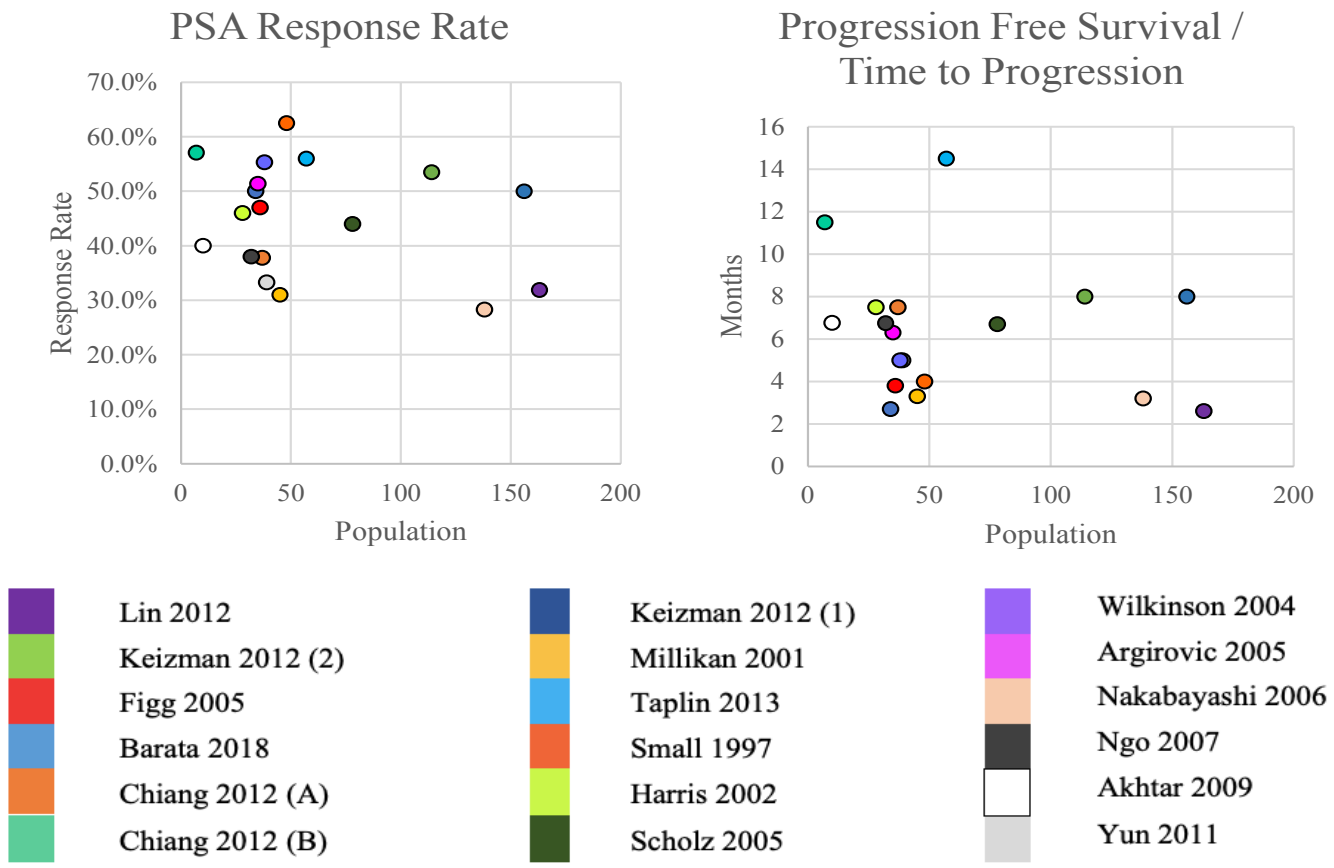

Figure 3. Scatterplot of PSA Response Rates and Progression-free Survival Durations from the Analyzed Studies 
inhibitor, which inhibits CYP17A1, a catalyst for two key reactions in the production of gonadal and extragonadal steroid hormones, namelyandrogen and testosterone (Almassi et al., 2018; Moher et al., 2010).

Another mechanism that may influence the pathogenesis of CRPC involves the effect of ketoconazole on $\mathrm{T}$ cell proliferation. In this case, cytochrome $\mathrm{P} 450$ regulates the influx of $\mathrm{Ca}^{2}+$ ions in $\mathrm{T}$ cells and causes inhibition of interleukin (IL) -2 synthesis and T24 cell proliferation (Jensen et al., 1999).

The adrenal cortex produces $10-30 \%$ of serum androgens, including androstenedione, dehydroepiandrosterone (DHEA), and dehydroepiandrosterone sulfate (DHEAS). Free and serum testosterone suppression is obtained within 2 hours of oral ketoconazole consumption, with maximum suppression after 8 hours. The testosterone suppression effect of ketoconazole is rapid and reversible, and normal testosterone levels are restored within 24 hours. Inhibition of CYP17A1 in the androgen synthesis pathway plays a significant role in ketoconazole's action against castration resistance. Androgen depletion therapy generally inhibits gonadal androgen synthesis, while ketoconazole inhibits both gonadal and adrenal androgen synthesis simultaneously (Patel et al., 2018). Furthermore, another source of androgen in prostate cancer is the de novo androgen synthesis in prostate cancer cells, mediated by CYPA1 and 3 $\beta$-dehydroxysteroid dehydrogenase isoenzyme 1 (3ßHSD1 or HSD3B1). HSD3B1 activity increases extragonadal androgen precursor conversion to intratumoral androgen, making ketoconazole's extragonadal activity even more potent against intratumor androgen levels in patients with high HSD3B1 activity (Almassi et al., 2018; Moher et al., 2010).

Ketoconazole for the treatment of MCRPC can be administered with three approaches: (1) a low dose regimen of $200 \mathrm{mg}$, tid, increased to $400 \mathrm{mg}$, tid if PSA response is not achieved within 3 months; (2) a high-dose regimen of $400 \mathrm{mg}$, tid, lowered to $200 \mathrm{mg}$ if the patient exhibited gastrointestinal intolerance or toxicity symptoms; or (3) an intermediate-dose of $300 \mathrm{mg}$, tid. The patients received ketoconazole on an empty stomach, either one hour before or two hours after eating, unless this resulted in nausea or gastrointestinal upset, in whom the ketoconazole was taken at mealtime (Harris et al., 2002; Milikan et al., 2001). Corticosteroids used for replacement therapy include hydrocortisone, $30 \mathrm{mg}$ in the morning and $10 \mathrm{mg}$ in the evening, or prednisone, $5 \mathrm{mg}$, bid (Millikan et al., 2001; Harris et al., 2002). In our study, in 17 extracted studies, it was concluded that ketoconazole significantly reduced more than fifty percent PSA value with or without corticosteroids or other adjuvants. It may be chosen for alternative ADT for metastatic CRPC patients especially in developing countries that cant afford abiraterone acetate or enzalutamide.

Inhibition of adrenal steroids by agents such as ketoconazole is the standard therapy for mCRPC, although the serological and radiographic benefits are not significant, and progression-free survival generally does not exceed 8-10 months. PSA evaluation can be conducted monthly, as done by Barata et al., (2018). In addition, an early decrease of PSA was detected within the first four weeks in Yun et al., (2011)' study. All of the analyzed studies reported a significant decrease in serum PSA $(>50 \%)$ in mCRPC patients receiving ketoconazole. Eight studies reported PSA response in $>50 \%$ of patients, while Scholz et al., reported an even greater decrease of PSA ( $>75 \%)$ in $44 \%$ of patients. Chiang et al., (2012) reported a greater decrease in PSA in the group receiving mg ketoconazole at dose of 400, compared to the group receiving ketoconazole at dose of $200 \mathrm{mg}$.

Signs of toxicity must be closely monitored, and the treatment with ketoconazole should be ceased immediately if grade 3 or 4 toxicity occurred. In grades $<3$ toxicity, the patients should be monitored for the signs, and this management should be continued until disease progression.

In conclusion, ketoconazole with corticosteroid replacement can be used as an anti-androgenic treatment option for docetaxel-naïve mCRPC, with satisfactory PSA response and progression-free survival.

\section{Author Contribution Statement}

All authors discussed the results and contributed to the preparation of the final manuscript.

\section{Acknowledgements}

Not applicable.

Conflict of Interest

The authors have no conflict of interest to declare.

\section{References}

Akhtar PS, Chowdhury RA, Masud J (2009). Efficacy of ketoconazole in hormone refractory prostate cancer patients. J Med, 10, 52-5.

Almassi N (2018). HSD3B1 and response to a nonsteroidal CYP17A1 inhibitor in castration-resistant prostate cancer. JAMA Oncol, 4, 554-7.

American Cancer Society medical and editorial content team. Chemotherapy for Prostate Cancer. Treating Prostate Cancer 2019 [cited 20209 September].

Argirović Đ (2005). An evaluation of high-doses ketoconazole with hydrocortisone substitution in hormone-refractory prostate cancer. Acta Chirurgica Iugoslavica, 52, 51-4.

Barata PC (2018). Ketoconazole plus Lenalidomide in patients with Castration-Resistant Prostate Cancer (CRPC): results of an open-label phase II study. Invest New Drugs, 36, 1085-92.

Bray F (2018). Cancer statistics 2018: GLOBOCAN estimates of incidence and mortality worldwide for 36 cancers in 185 countries. CA Cancer J Clin, 68, 394-424.

Budiarto W, Sugiharto M (2013). Biaya Klaim INA CBGs dan Biaya Riil Penyakit Katastropik Rawat Inap Peserta Jamkesmas di Rumah Sakit Studi di 10 Rumah Sakit Milik Kementerian Kesehatan Januari-Maret 2012. Buletin Penelitian Sistem Kesehatan, 16, 21375.

Chiang BJ (2012). Ketoconazole in Taiwanese castrationresistant prostate cancer patients: Evaluation of response rates, durations, and predictors. Urol Sci, 23, 48-51.

Fong MK, Hare R, Jarkowski A (2012). A new era for castrate resistant prostate cancer: a treatment review and update. J Oncol Pharm Pract, 18, 343-54.

Frieling JS, Basanta D, Lynch CC (2015). Current and emerging 
therapies for bone metastatic castration-resistant prostate cancer. Cancer Control, 22, 109-20.

Global Burden of Disease Cancer Collaboration, Global, regional, and national cancer incidence, mortality, years of life lost, years lived with disability, and disability-adjusted life-years for 29 cancer groups, 1990 to 2017: a systematic analysis for the global burden of disease study. JAMA Oncol, 5, 1749-68.

Harris KA (2002). Low dose ketoconazole with replacement doses of hydrocortisone in patients with progressive androgen independent prostate cancer. J Urol, 168, 542-5.

Jensen BS (1999). Inhibition of T cell proliferation by selective block of $\mathrm{Ca} 2+$-activated $\mathrm{K}+$ channels. Proc Nat Acad Sci US A, 96, 10917-21.

Keizman D (2012). Contemporary experience with ketoconazole in patients with metastatic castration-resistant prostate cancer: clinical factors associated with PSA response and disease progression. Prostate, 72, 461-7.

Keizman D (2012). Pretreatment neutrophil-to-lymphocyte ratio in metastatic castration-resistant prostate cancer patients treated with ketoconazole: association with outcome and predictive nomogram. Oncologist, 17, 1508.

Komite Penanggulangan Kanker Nasional, Panduan Penatalaksanaan Kanker Prostat. 2016, Kementerian Kesehatan Republik Indonesia: Jakarta.

Lin G-W (2012). The prognostic factors of effective ketoconazole treatment for metastatic castration-resistant prostate cancer: who can benefit from ketoconazole therapy?. Asian J Androl, 14,732 .

Millikan R (2001). Randomized phase 2 trial of ketoconazole and ketoconazole/doxorubicin in androgen independent prostate cancer. in Urologic Oncology: Seminars and Original Investigations. 2001. Elsevier.

Moher D (2010). Preferred reporting items for systematic reviews and meta-analyses: the PRISMA statement. Int $J$ Surg, 8, 336-41.

Nakabayashi M (2006). Response to low-dose ketoconazole and subsequent dose escalation to high-dose ketoconazole in patients with androgen-independent prostate cancer. Cancer Interdisciplinary Int J Am Cancer Soc, 107, 975-81.

National Institute of Health, LiverTox: clinical and research information on drug-induced liver injury. Nih. gov https:// livertox. nih. gov, 2017.

Ngo LS (2007). Efficacy of low-dose ketoconazole in hormone refractory prostate cancer patients at the National Cancer Centre and The Cancer Institute, Singapore. Ann Acad Med Simgapore, 36, 811 .

Patel V, Liaw B, Oh W (2018). The role of ketoconazole in current prostate cancer care. Nat Rev Urol, 15, 643-51.

Rawla P (2019). Epidemiology of prostate cancer. World $J$ Oncol, 10, 63.

Scholz M (2005). Long-term outcome for men with androgen independent prostate cancer treated with ketoconazole and hydrocortisone. J Urol, 173, 1947-52.

Sinawe H. Ketoconazole. StatPearls Knowledge Base 2020 [cited 20209 September];

Taplin M-E (2009). Phase II study of androgen synthesis inhibition with ketoconazole, hydrocortisone, and dutasteride in asymptomatic castration-resistant prostate cancer. Clin Cancer Res, 15, 7099-7105.

Teo MY, Rathkopf DE, Kantoff P (2019). Treatment of advanced prostate cancer. Ann Rev Med, 70, 479-99.

Wilkinson S, Chodak G (2004). An evaluation of intermediatedose ketoconazole in hormone refractory prostate cancer. Eur Urol, 45, 581-5.

Yun BH (2011). Comparison of ketoconazole and estramustine for treating patients with castration-resistant prostate cancer.
A Systematic Review on the Efficacy of Ketoconazole

Korean J Urol, 52, 746-51.

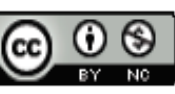

This work is licensed under a Creative Commons AttributionNon Commercial 4.0 International License. 